\title{
Proposition and Test of a Quality Assessment Extension WebQual Model in Brazil
}

\author{
Nivia Elaine Haddad Rezende ${ }^{1}$, Luiz Rodrigo Cunha Moura ${ }^{1}$, Fernanda Carla Wasner Vasconcelos ${ }^{1} \&$ Nina \\ Rosa da Silveira Cunha ${ }^{2}$ \\ ${ }^{1}$ School of Management, Centro Universitário UNA, Belo Horizonte, Brasil \\ ${ }^{2}$ School of Management, Universidade Federal de Viçosa, Viçosa, Brasil \\ Correspondence: Luiz Rodrigo Cunha Moura, School of Management, Centro Universitário UNA, Rua \\ Guilherme de Almeida, 191/702, Belo Horizonte, Minas Gerais, Brasil. Tel: 55-319-9634-3272. E-mail: \\ luizrcmoura@gmail.com
}

Received: January 18, 2017

Accepted: January 29, 2017

Online Published: March 31, 2017

doi:10.5539/res.v9n2p74

URL: http://doi.org/10.5539/res.v9n2p74

\begin{abstract}
This study has a purpose to test the extended WebQual Model from the inclusion of the construct familiarity has nomological validity, besides to verify the explained variance to satisfaction and intention to reuse are higher in the extended model than the original model. The quality evaluation WebQual model presents a measurement process from twelve constructs: information fit-to-task, tailored information, on-line completeness, relative advantage, easy of understanding, intuitive operations, trust, response time, visual appeal, innovativeness, emotional appeal and consistent image. Constructs familiarity, satisfaction and intention to reuse by users were included in this model. Data were collected by electronic means, and at the end, 456 questionnaires were obtained from the Rede Habitar portal and 240 questionnaires from Rede Imvista portal, totalizing 696 questionnaires. Obtained results indicate that the analyzed portals quality evaluation is reasonable, which all one-dimensional indices, reliability, and convergent validity showed suitable results. In the discriminant validity, only two correlations did not show proper values. Nomological validity was achieved and the relationship between the extended model constructs were shown suitable. In explained variance terms, the construct familiarity insertion increased the indicator's value for satisfaction, however it should also be considered the lack of discriminant validity between familiarity and satisfaction.
\end{abstract}

Keywords: webqual, digital marketing, site assessment, networking portal, scale validation, perceived quality

\section{Introduction}

The volume increase of e-commerce business worldwide shows the importance of e-commerce investigation, evaluation websites, design solutions, quality, consumer behavior on the web, and factors that influence it (Davidavicenè \& Tolvaisas, 2011). A website's management must support an approach focused on the customer experience and will only be well understood if it builds on quality services delivery in the current environment and future trends (Borges, Veiga, Gonçalves Filho, \& Fernandes, 2014). There is great consumer's interest about a site quality, being represented by their information, content, services on the Web, and others (Nawi \& Al-Mamun, 2014). Information technology diffusion in people's lives is important, whether at home or in the workplace, creating an interaction with the technology provided by the companies and, consequently, technology interfaces have become the key for business success (Bolar, 2014). One of the currently tested models is the WebQual, as can be seen in studies by Ferreira (2015), Sun, Wang, Yang and Zhang (2015) and Ferreira (2012).

In addition to testing the WebQual Model Loiacono, Watson and Goodhue, this study has the purpose to also verify whether the WebQual extended model (Loiacono et al., 2007) with the inclusion of the construct familiarity is valid. Besides that, it identifies the existent or not relationship between the perceived quality, satisfaction and intention to reuse, and to verify whether the construct familiarity inclusion will increase the explained quality perceived variance by two real estate portal users.

This study theoretical importance can be described in terms of WebQual original model's validation and testing of its length with the construct familiarity inclusion. Also, in the internet environment is verified the perceived quality consequences and the effects, especially in terms of satisfaction and intention to reuse the portals used in 
this study. Not only the perceived quality, but mainly the customer loyalty to the site is something important to be identified and analyzed, considering that keeping users visiting a website is marketers linked to e-commerce main goal (Heijden, 2000).

Portals measurement quality should disclose information beyond the statistics so that administrators have condition to understand the reason for visitor's preference or rejection. For this reason, considering consumers' behavior to obtain study directly involved activities, consume and dispose of goods and services, including decision-making processes preceding and following the actions, become important to know and study these interactions (Ferreira, 2015; Curi, Dias, \& Gonçalves Filho, 2006).

From the service provider's perspective and consumer, it can be seen the importance the services ways are organized. This view is the difference that allows companies earn higher profits, leading to greater customer loyalty and protecting competitors' attacks company supply (Sa, Rocha, \& Cota, 2015; Yasin \& Aziz, 2010). The WebQual is an instrument which aims to measure the customer's perceived quality, facilitating managers' decision work (Anand, Mittal, Moolchandani, Kagzi, \& Kar, 2015; Sun et al., 2015; Petruzzellis, D’uggento, \& Romanazzi, 2006).

\section{Theoretical Foundations}

Theoretical framework basically presents the components of WebQual Model Loiacono et al. (2007), as well as construct familiarity and the site's quality perceived consequences in satisfaction and intention to reuse terms.

\subsection{Quality and WebQual Model}

The WebQual Model was developed from the customer's perspective and its perception as a websites user searching that way, develop a measurement tool to the websites quality. Having as theoretical foundations, initially, the analysis of existing measurement tools: The Theory of Reasoned Action (TRA) and the Theory of Acceptance Technology (TAM), which later developed and improved through its application to use websites (Sun et al., 2015; Ferreira, 2015; Rodrigues, 2012). The dimensions and constructs are described in Table 1.

Table 1. Constructs and dimensions WebQual Model (adapted from Loiacono, Watson, \& Goodhue, 2000; Loiacono et al., 2007; Rodrigues, 2012)

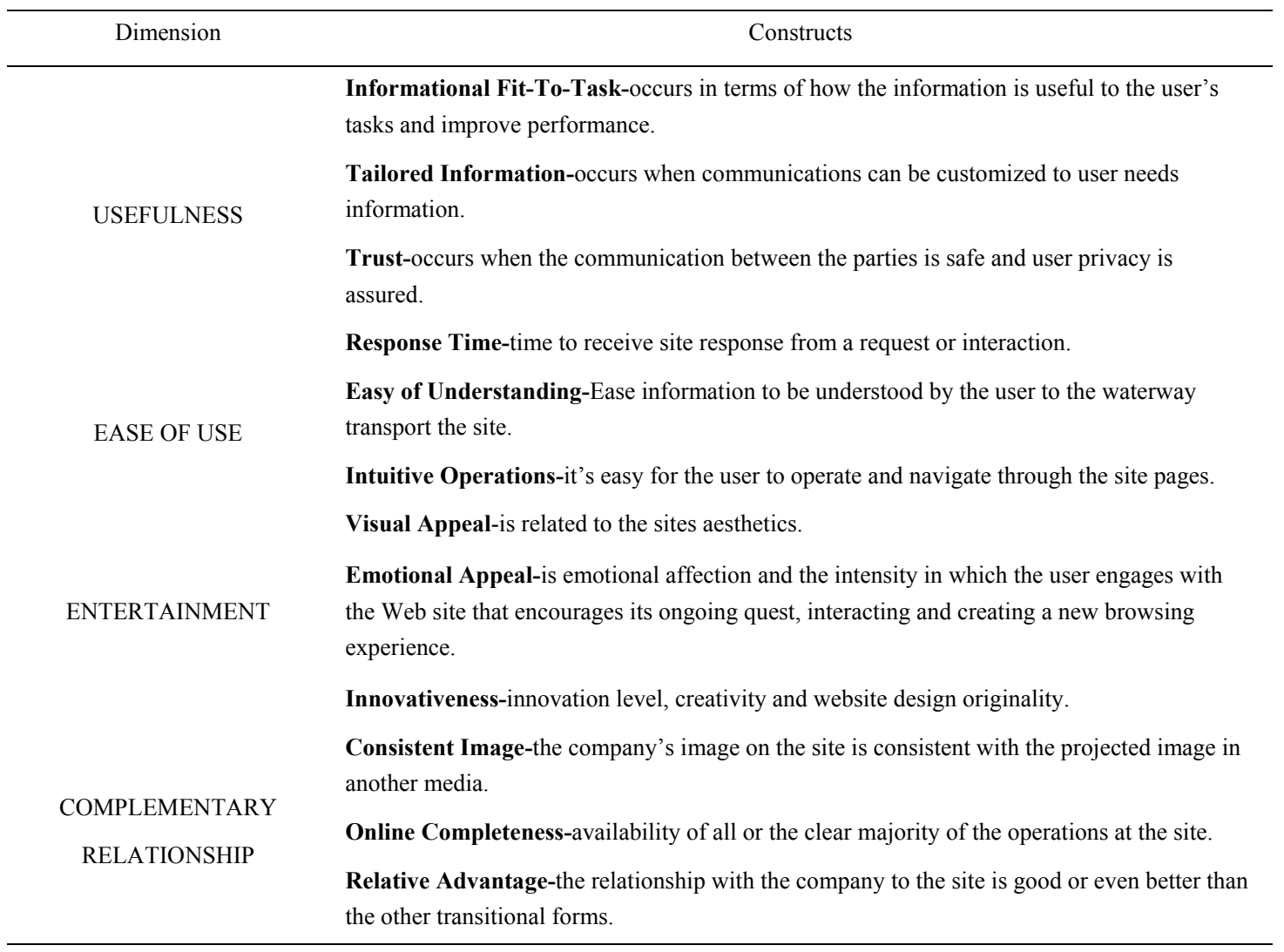


The site's quality is important to consider-according to the users' perception-directly affects their intentions to use or not a website, a very important item to be managed by those responsible for the site ( $\mathrm{Sa}$, Rocha, \& Cota, 2016; Anand et al., 2015; Chang, 2012).

\subsubsection{Usefulness - Informational Fit-to-Task, Tailored Information, Trust, and Response Time}

Customers seek information for two purposes: either to a pre-purchase research (information requested to facilitate a decision on a specific purchase target) or to a permanent search (independent of specific purchasing needs). A customer is simply browsing without the necessarily intention to buy in mind and a website's ability to provide information and communications tailored or customized to suit the users' specific needs is something important (Sun et al., 2015), and the site's ability to provide the necessary information demands by the user, that is the useful information (Loiacono et al., 2000).

Consumer's trust on the sites has been defined as a consumer's subjective belief that the selling party will fulfill its transactional obligations (Kim, Ferrim, \& Rao, 2003) in the evaluation that the user feels in terms of considering your personal information to the site (Prado, 2010) is achieved when a product or service is delivered in accordance with what is offered and described by the service provider (Sa et al., 2016). Trust is important because of the risk associated with websites in general is bigger than the perceived risk in relation to physical or traditional stores (Masoud, 2013).

Response time is the dimension that checks the waiting time between a user action and answer website, as well as the time it takes to load (Ferreira, 2015; Prado, 2010) and access speed and availability, the site measures searching time and number of clicks to access the landing page that should be as short as possible (Rodrigues \& Andrade, 2011). This response time depends on issues that are beyond the site manager's reach however, there are also those to which they have decision-making power, such as configurations and software versions (Franco \& Carlos, 2013). Response time is important to not frustrate the user, and encourage them to go to other sites (Loiacono et al., 2007).

\subsubsection{Ease of Use-Easy of Understanding and Intuitive Operations}

Effective information search, efficient and easy access to the site is valued by users. For e-commerce, visitors prefer to access relevant product information quickly and with fewer clicks. Consumers also value the product comparisons to ensure the best making purchasing decision (Rodrigues \& Andrade, 2011) the most effective site is not the most sophisticated however, it is the easiest to use (Belanche, Casalo, \& Guinali'u, 2011), allowing for an easy navigation through the site (Ferreira, 2015).

Consumers who noticed a great risk enhanced the usability's influence, probably because the usability helps to overcome these risks and form a more favorable website's opinion use (Belanche et al., 2011). Usability occurs when all site parts and all links in and out of the site work properly: navigation, readable content, page layouts, simple instructions, and easy search functions also contribute to the ease use of the site (Dominic \& Jati, 2011), referring to the ease and simplicity a user faces in navigating through a site (Sa et al., 2016) or the degree to which a person realizes how little effort it would have to take or check the functionality and information from a computer system (Davis, 1989).

Two distinct aspects of the easy use dimension are the easy information to read and understand exhibition, easily operation and navigate through the site are two distinct, for each website page can be easy to read and understand, however navigation between pages can be difficult (Loiacono et al., 2000).

\subsubsection{Entertainment-Visual Appeal, Emotional Appeal and Innovativeness}

Entertainment dimension refers to stimuli that will provide a pleasant and enjoyable browsing experience. Constructs that make up this dimension consider aesthetic and emotional aspects, and the site's innovative character in relation to other similar sites (Curi et al., 2006). The site should create a pleasant experience for consumers looking for the full experience (Loiacono et al., 2000).

A site's innovation is on the creativity and uniqueness that provides in its use, and the site design is its aesthetic aspect, the use of colors and compelling multimedia features, as well as organization aspects (Sa et al., 2016) with the site being visually appealing and inviting with a creative or innovative touch (Loiacono et al., 2007).

\subsubsection{Complementary Relationship-Consistent Image, Online Completeness and Relative Advantage}

In terms of a site's consistent image, it must match the desired image for the company, with the image the user has of the company and combine with the company's image (Rodrigues, 2012). Consistent image is an important factor in the quality perceived by the customer (Loiacono et al., 2007). In the case of online integration, it is 
related to the features offered by the site, such as making online purchases and services and business offered by sites (Rodrigues, 2012).

Finally, the relative advantage is described how the site can be considered a viable alternative to traditional relationship means and interaction with sites. Some examples can be described in an easier use to the site terms then the phone, email or company representative (Rodrigues, 2012; Loiacono et al., 2007).

\subsection{Familiarity}

Familiarity is the realization of an online business, often based on previous interactions, the experience and learning what, who, how and when it is happening. In an e-commerce environment, familiarity refers to a common form how a user knows the supplier and to what extent the site procedures, how to navigate the site, where to find certain information, and when and how to enter payment information. Familiarity serves to reduce social complexity by providing an understanding of it (Mccoy et al., 2008). In general, familiarity is related to the previous experience level and knowledge with something of interest (Thatcher, Carter, Li, \& Rong, 2013).

A website design is associated with the perception of the consumer organization and order on site, and is also a key factor for customer satisfaction with the experience and consequently generating familiarity (Nawi \& Mamun, 2014), in which reinforces the call for many stimuli possibilities for the user (Mcdougall, Reppa, Kulik, \& Taylor, 2016). Users familiarization with a website is an important concept in online trading. Being familiar with a website is not the same as trusting the site, however those two concepts are closely related. Increased confidence is often the result of the credibility that comes with a family business or website (Mccoy et al., 2008) and familiarity reduces uncertainty, increasing confidence in online contexts (Thatcher et al., 2013).

\subsection{Satisfaction}

Satisfaction is described as an individual subjective emotion, resulting from a favorable assessment of the experience associated with a product or service consumption. It is an assessment, describing the overall consumption experience based on a mixture of interactions between the consumer and the service provider (Chang, Jeng, \& Hamid, 2012; Chen, Hsiao, \& Hwang, 2012), being defined as an affective condition that results from an overall assessment - it is a crucial antecedent to re-purchase intentions and a product or service re-use. Satisfaction with previous use is also found to be the strongest predictor of continuity users' intentions. Empirically satisfaction is a key determinant of customer preference and their study is valuable to explain why consumers buy products or repurchase exposes the motivations underlying consumer behavior (Chen et al., 2012).

In several studies (Lima, Moura, \& Souki, 2015; Chang et al., 2012; Vieira, Matos, \& Slongo, 2009), the quality is a satisfaction predecessor and to a behavioral intention or loyalty too. It is an important point because, justifies the quality consequences presence seen in the tested conceptual model (satisfaction and intention to reuse).

\subsection{Intention to Reuse}

An intended use is what is expected to happen (Bolar, 2014) and businesses and online stores typically spend significant sums of money to build and maintain their websites, because their performance depends on the users' judgment about their intention to use its sites more often (Belanche et al., 2011).

The site utilization, also influences the consumer's intention to use it. It may depend on the result of a good usability management to the site. Thus, managers must not forget the usability in their website's design. In fact, consumers have different skills in the management and site control, they can recognize different risk levels, when interacting with a website (Belanche et al., 2011). In the case of WebQual Model, it helps managers to identify the factors responsible for site reuse (Anand et al., 2015).

\section{Hypothetical Model}

From the above, and using the original WebQual Model Loiacono et al. (2007), also considering the inclusion of the construct familiarity and quality consequences for the satisfaction and intention to reuse, the following hypothetical model is proposed, presented in Figure 1. 


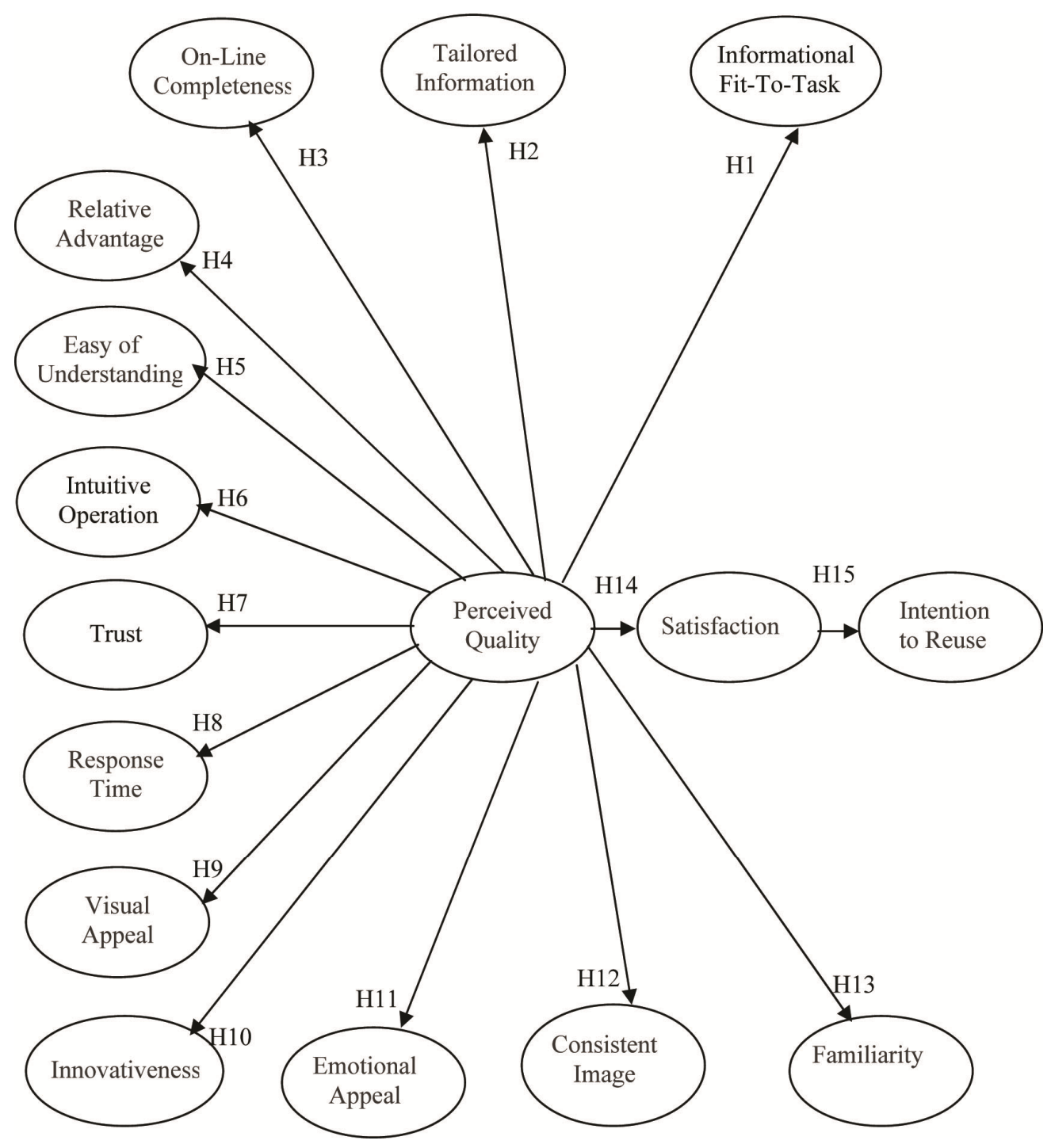

Figure 1. Hypothetical Model (adapted from Loiacono et al., 2007)

From the picture one it can be describing the following assumptions:

Hypothesis 1: Perceived quality is reflected by the informational fit-to-task.

Hypothesis 2: Perceived quality is reflected by the tailored information.

Hypothesis 3: Perceived quality is reflected by the on-line completeness.

Hypothesis 4: Perceived quality is reflected by the relative advantage.

Hypothesis 5: Perceived quality is reflected by the ease of understanding.

Hypothesis 6: Perceived quality is reflected by the intuitive operation.

Hypothesis 7: Perceived quality is reflected by the trust.

Hypothesis 8: Perceived quality is reflected by the response time.

Hypothesis 9: Perceived quality is reflected by the visual appeal.

Hypothesis 10: Perceived quality is reflected by innovativeness.

Hypothesis 11: Perceived quality is reflected by the emotional appeal.

Hypothesis 12: Perceived quality is reflected by consistent image.

Hypothesis 13: Perceived quality is reflected by familiarity. 
Hypothesis 14: There is a positive association between perceived quality and satisfaction.

Hypothesis 15: There is a positive association between satisfaction and intention to reuse.

Hypothesis 16: Explained variance for satisfaction is higher in the extended model than the original WebQual Model.

Hypothesis 17: Variance explained to the intention to reuse is higher in the extended model than the original WebQual Model.

\section{Method}

The study method began with the target audience research's definition (Habitar Portal users and Imvista Portal), with the data collection definition form (electronic forms for data collection) data collection instrument and the sampling procedure (for convenience). This is a descriptive study using the quantitative data analysis approach.

Regarding the portals, they are different from websites, they provide a mix of information, applications and services (Granic, Mitrovic, \& Imarangunic, 2010) and its main functions are to gather information from different sources to create a single point of access point to information and provide to a person or their personal interests services relevant to the work (Rodrigues \& Andrade, 2011).

For the data collection instrument preparation, the following study related to the constructs were considered:

- Constructs of WebQual and Intent to Reuse (Loiacono et al., 2000, 2007; Rodrigues, 2012; Raposo, Pereira, \& Santos, 2008).

- Familiarity (McCoy et al., 2008).

- Satisfaction and perceived quality (Fornell, Johnson, Anderson, Cha, \& Bryant, 1996; Lima et al., 2015).

The interval scale had as fundamentals, agreement or disagreement degree to the ones who were interviewed by indicting; "strongly disagree" and "strongly agree", with the staggering number ranging from " 0 " to " 10 ". The interval scale choice with eleven points is a function that can record more detail and more accurately the changes in opinions of respondents (Nunnaly \& Bernstein, 1994; Fornell et al., 1996).

Before the questionnaire was carried out a pre-test with 45 customers of these sites, in order to identify possible problems with writing, clarity, and scheduling options and wording of questions. No changes needed to be made, despite respondents' complaining of in questionnaire size terms, as well as the perception that the questions are quite similar.

Data were collected through electronic means in non-probability sampling, chosen for convenience, because of limitations on the process randomness of probability sampling technique. The questionnaire was available to electronic portals Rede Habitar and Rede Imvista users through links to their fill. At the end, 456 questionnaires were obtained coming from the electronic portal of Habitar and 240 questionnaires coming from the electronic portal Imvista, totaling 696 questionnaires.

As the sample size and considering the multivariate statistical analyzes were carried out, the sample contains a case number of at least 10 items for each questionnaire question. The number of 696 questionnaires was considered satisfactory, even with the knowledge that there would still be the disposal of the sample elements from outlier's multivariate analysis.

\section{Results/Discussion}

\subsection{Sample Characteristics and Data Treatment}

The initial sample consisted of 696 questionnaires total. Depending on the electronic data collection instrument used, there was no occurrence of missing data.

In multivariate outliers' terms, its verification occurred by calculating the distance $\mathrm{D}^{2}$ of Mahalanobis and compared to the value of the $X^{2}$ test considering the degree's number of freedom the variables number that will be used in multivariate statistical techniques. Thus, all values above 86.66 (50 freedom degrees and a significance 0.001 ) were removed from the sample. Thus, they identified and removed one hundred and eight outliers. Therefore, the final sample got five hundred eighty-eight elements. Then it was evaluated the sample's normality or not used by the Kolgomorov-Smirnov Test (Malhotra, 2013) and no question presented normal distribution.

Regarding the sample characteristics were 415 (70.6\%) respondents evaluating the portal Habitar and 173 (29.4\%) respondents evaluating the portal Imvista. Most respondents are woman, totalizing 328, with 55.8\%. The age range of a larger size was $42-49$ years, with 186 respondents, representing $31.6 \%$. Second comes the 
34-41 age group with 166 respondents and percentage of $28.2 \%$. Most respondents have higher level or graduate and has monthly income up to five minimum wages or R $\$ 4.400 .00$ four thousand and four hundred Reais, in force in the year 2016.

\subsection{One-Dimensionality and Reliability}

The verification if each of the constructs refers to only one dimension was performed by 15 exploratory factor analysis (hypothetical model has constructs 15 and 46 items in total). The results were appropriate, each of the 15 constructs generated only one factor.

To carry out the exploratory factor analysis, three conditions must be met. The first one refers to the correlation between items that form a construct. These items should have significant correlations with each other. The second assumption concerns the Bartlett Sphericity Test, which should show a significant correlation at the level of $95 \%$ (Morgan \& Griego, 1998). Finally, there is the Adequacy Test Sample of KMO (Kaiser-Meyer-Olkin) with values above 0.60 are acceptable for exploratory research, and the ideal values are above 0.80 (Malhotra, 2013; Hair, Black, Babin, Anderson, \& Tathan, 2009).

The results shown in Table 7 (see Appendix A) show that all the conditions have been met and the components and standardized load had also suitable values.

Another factor to be considered is each of the constructs scales reliability. For this is calculated Cronbach's Alpha for each of the model tested constructs. The Cronbach's Alpha ranges from 0 to 1 and values above 0.60 for exploratory studies and 0.70 for scales previously validated are values considered adequate (Malhotra, 2013; Hair et al., 2009).

The values shown in Table 7 (see Appendix A) indicate that the reliability has been achieved for all fifteen constructs present in the model, and all constructs showed values above 0.80 .

\subsection{Validity Convergent and Discriminant Validity}

The next item discussed was the convergent validity, which is verified by the values of Average Variance Extracted (AVE) and composite reliability (CC), in addition to the standard load values. Therefore, the AVE value should be above 0.50 . The $\mathrm{CC}$ must have values above 0.70 and standardized factor loadings of the indicators should be at least 0.50 (Hair et al., 2009). The results indicate that all the conditions for convergent validity verification were achieved.

Finally, this topic was verified discriminant validity among all constructs. It was calculated the correlation between all the constructs by pairs and compares this value with the correlation square root value AVE of the constructs. The correlation value must be less than the AVE square value (Hair et al., 2009).

The total of one hundred and five possible combinations, only two of these combinations, the correlation value between the two constructs was greater than the AVE square root value. These relationships are between online completeness and innovativeness; and satisfaction and familiarity.

A more serious problem is the lack of discriminant validity, because of these constructs have a causal relationship in nomological chain. Moreover, the lack of discrimination between familiarity and satisfaction may compromise the extended model analysis because it is precisely checked for familiarity construct insertion on the model and the variance explained improved quality, satisfaction and intention to reuse the site.

\subsection{Validity Nomological}

The analysis process of nomological validity occurs by the realization of Structural Equation Modeling (SEM) for each of the two studied models. At this stage, the measurements values were checked together and tested models (original WebQual and WebQual extended with the construct familiarity inclusion).

Prior to analysis, it is necessary to point out that the two SEM were performed through the generalized least squares estimation method, because of the lack of normality between the variables to be included in the model. They also calculated all the covariance between exogenous constructs to get a better view about the relationships between all the variables that make up the original and modified theories tested in this research.

Regarding the 1st order constructs analysis, the results were positive. In Table 7 (see Appendix A), it can be identified the standard values of all items in all constructs loads have appropriate values and SEM results show that all relationships are statistically significant. So as much as for the original Webqual Model, and for the WebQual Model Extended with the construct familiarity inclusion, all indicators are significant in statistical terms for all their constructs. Most of the indicators has a value standardized for the load above 0.90 which is a significant value in absolute values. 


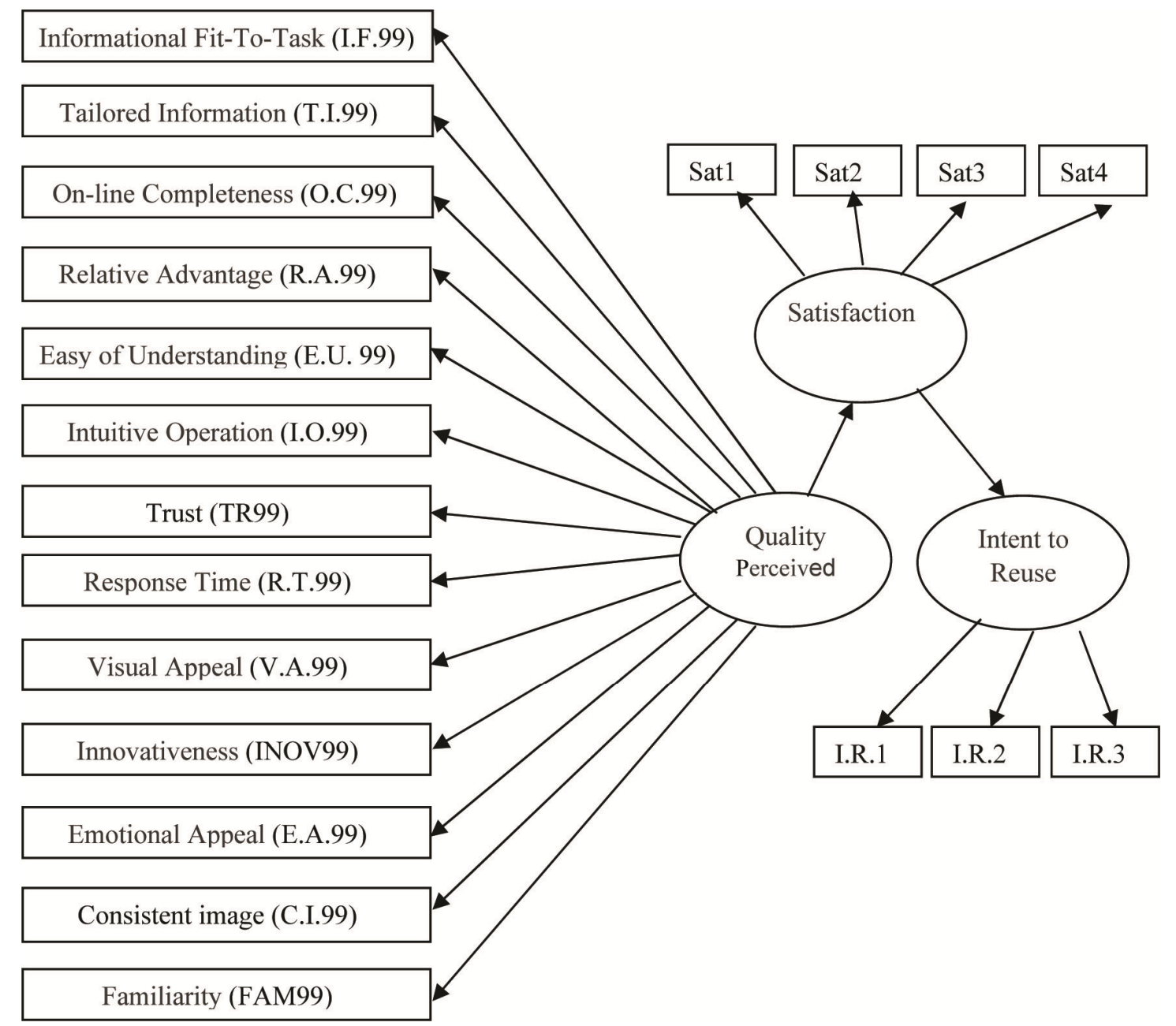

Figure 2. WebQual model extended 2nd order

These indicators were formed by each construct's average. For example, the relative advantage indicator (R.A.99) was formed by the average of the three indicators (R.A.1+R.A.2+R.A.3/3) that form the construct perceived value in the case of calculating the first order indicator.

In the case of calculating the perceived quality construct, it will be formed by the original 12 indicators of WebQual model increased by familiarity construct.

Table 2 shows the results for relations considering the second order constructs (satisfaction, perceived quality and intent to reuse) for the original WebQual Model Loiacono et al. (2007), and for the WebQual Model Extended.

Table 2. Meaningfulness between the 2nd order constructs relations

\begin{tabular}{|c|c|c|c|c|}
\hline \multicolumn{3}{|c|}{ Relation between the Constructs } & \multirow{2}{*}{$\begin{array}{c}\text { Standard Load Original } \\
\text { WebQual } \\
0.9462\end{array}$} & \multirow{2}{*}{$\begin{array}{c}\begin{array}{c}\text { Standard Load } \\
\text { Extended } \\
\text { WebQual }\end{array} \\
0.9929\end{array}$} \\
\hline Satisfaction & $<---$ & Perceived Quality & & \\
\hline Intent to Reuse & $<---$ & satisfaction & 0.8559 & 0.8493 \\
\hline SAT1 & $<---$ & satisfaction & 0.9875 & 0.9904 \\
\hline SAT2 & $<---$ & satisfaction & 0.9887 & 0.9879 \\
\hline SAT3 & $<---$ & satisfaction & 0.9893 & 0.9893 \\
\hline
\end{tabular}




\begin{tabular}{cllll}
\hline SAT4 & $<---$ & satisfaction & 0.9775 & 0.9773 \\
I.R.1 & $<---$ & Intent to Reuse & 0.9917 & 0.9921 \\
I.R.2 & $<---$ & Intent to Reuse & 0.9963 & 0.9961 \\
I.R.3 & $<---$ & Intent to Reuse & 0.9856 & 0.9851 \\
I.F.99 & $<---$ & Perceived Quality & 0.9645 & 0.9629 \\
T.I.99 & $<---$ & Perceived Quality & 0.9724 & 0.9706 \\
R.A.99 & $<---$ & Perceived Quality & 0.9323 \\
TR99 & $<---$ & Perceived Quality & 0.9350 & 0.9587 \\
R.T.99 & $<---$ & Perceived Quality & 0.9604 & 0.9346 \\
E.U.99 & $<---$ & Perceived Quality & 0.9366 & 0.9828 \\
I.O.99 & $<---$ & Perceived Quality & 0.9835 & 0.9675 \\
V.A.99 & $<---$ & Perceived Quality & 0.9691 & 0.9548 \\
INOV99 & $<---$ & Perceived Quality & 0.9568 & 0.9648 \\
E.A.99 & $<---$ & Perceived Quality & 0.9654 & 0.9673 \\
C.I.99 & $<---$ & Perceived Quality & 0.9643 & 0.9704 \\
O.C.99 & $<---$ & Perceived Quality & 0.9736 & 0.9471 \\
FAM99 & $<---$ & Perceived Quality & 0.9469 & 0.9913 \\
\hline
\end{tabular}

It can be seen in relation to Table 2 that relations have high values for the standardized factor loadings and although it is not shown in this table, it is necessary to consider that all relations between the items statistical significance.

\subsection{Hypothesis Test}

Results presented in Table 3 indicate that in relation to the website's quality, all twelve factors present in the original WebQual Model of Loiacono et al. (2007) reflect the users perceived quality of real estate portals that were evaluated in this study. Therefore, the hypothesis H1 to H12 are supported.

Furthermore, there was the construct familiarity inclusion to WebQual Model Loiacono et al. (2007). The results indicate that the hypothesis 13 was supported, namely the familiarity also reflects the quality perceived by customers.

In the case of $\mathrm{H} 14$ and $\mathrm{H} 15$ hypotheses the results indicate that the relationships between perceived quality and satisfaction constructs and also between the constructs satisfaction and intent to reuse are significant and positive.

Table 3. Hypotheses search verification

\begin{tabular}{ll}
\hline \multicolumn{1}{c}{ Hypotheses } & Results \\
\hline H1: Perceived quality is reflected by the informational fit-to-task. & supported \\
H2: Perceived quality is reflected by the tailored information. & supported \\
H3: Perceived quality is reflected by the on-line completeness. & supported \\
H4: Perceived quality is reflected by the relative advantage. & supported \\
H5: Perceived quality is reflected by the ease of understanding. & supported \\
H6: Perceived quality is reflected by the intuitive operation. & supported \\
H7: Perceived quality is reflected by the trust. & supported \\
H8: Perceived quality is reflected by the response time. & supported \\
H9: Perceived quality is reflected by the visual appeal. & supported \\
H10: Perceived quality is reflected by innovativeness. & supported \\
\hline
\end{tabular}


H11: Perceived quality is reflected by the emotional appeal.

H12: Perceived quality is reflected by consistent image.

H13: Perceived quality is reflected by familiarity.

H14: There is a positive association between perceived quality and satisfaction.

H15: There is a positive association between satisfaction and intent to reuse.

H16: The explained variance for satisfaction is higher in the extended model than the original WebQual Model.

H17: The variance explained by the intention to reuse is higher in the extended model than the original WebQual Model. supported

supported

supported

supported

supported

supported

rejected

In the case of $\mathrm{H} 16$ and $\mathrm{H} 17$ hypotheses, they can be verified from the data presented in Table 4. A small decrease of variance explained $\left(\mathrm{R}^{2}\right)$ of the intention to construct reuse comparing the original Model of WebQual Loiacono et al. (2007) with the extended model appears, thus rejecting the H17 hypothesis.

There is an increase in the explained variance amount by the satisfaction construct considering the extended model, which supports H16. This increase can occur because it had no discriminant validity between constructs familiarity and satisfaction, and as in the conceptual model familiarity is an indirect satisfaction predecessor, by including familiarity consequently increases the satisfaction.

Table 4. Explained variance in the reuse intent construct

\begin{tabular}{ccc}
\hline Constructs & $\mathrm{R}^{2}$-Original Model & $\mathrm{R}^{2}$-Extended Model \\
\hline Satisfaction & $89.53 \%$ & $98.59 \%$ \\
Intent to Reuse & $73.25 \%$ & $72.13 \%$ \\
\hline
\end{tabular}

\subsection{Model's Fit Indices}

Another point to be analyzed in relation to SEM is the fit models. Per the data shown in Table 5, none of fit the indices has achieved the proper values.

Table 5. Fit indices for models tested

\begin{tabular}{cccc}
\hline Adjustment Measure & $\begin{array}{c}\text { Values Obtained } \\
\text { WebQual Model Original }\end{array}$ & $\begin{array}{c}\text { Values Obtained WebQual } \\
\text { Model Extended }\end{array}$ & Value Desire \\
\hline$X^{2}$ & 986.6164 & 1223.3162 & Hndefined \\
p-value & 0.0000 & 0.0000 & Higher than 0.05 \\
Degree of Freedom $(d f)$ & 150 & 168 & The largest possible above zero \\
$X^{2} / d f$ & 6.5774 & 7.2816 & Above 1 to 3 and complex Model to 5 \\
GFI (Godness Fit Index) & 0.8231 & 0.7916 & Above 0.03 and below 0.08 \\
\hline RMSEA (Root Mean Square Error of & 0.0975 & 0.01035 & \\
\hline
\end{tabular}

More complex models and with larger samples should be considered, 250 elements must have a less restrictive assessment of the values listed as suitable for setting indexes (Hair et al., 2009), or even index values are not achieved can evaluate these indices with values close to the reference. The two SEM made, the original WebQual Model has twelve constructs and the extended model has fifteen constructs.

From the results analysis, the two tested models have poor fit indices, wherein the unique WebQual Model has better values than WebQual template extended, although in general, the indices for the two models are well below the appropriate minimum. 


\section{Conclusion}

\subsection{Variance Explained}

Results indicate that the perceived quality evaluation of the analyzed portals is reasonable on the members part. The WebQual Model Loiacono et al. (2007) passed the tests and verifications related to the one-dimensionality, reliability and convergent validity, discriminant, and nomological.

Comparing the obtained results for the variance explained in reuse intention, it appears that the revealed index in this research is better than the study Loiacono et al. (2007), Loiacono, Chen and Goodhue (2002) and Curi et al. (2006), as can be seen in Table 6.

Table 6. Intent of explained variance comparison between studies in reuse

\begin{tabular}{cccccc}
\hline Construct & $\begin{array}{c}\text { Loiacono et al. } \\
(2002)\end{array}$ & $\begin{array}{c}\text { Loiacono et al. } \\
(2007)\end{array}$ & $\begin{array}{c}\text { Cury et al. } \\
(2006)\end{array}$ & $\begin{array}{c}\text { Webqual Original } \\
\text { (this research) }\end{array}$ & $\begin{array}{c}\text { Webqual Extended with } \\
\text { the Construct Familiarity }\end{array}$ \\
\hline $\begin{array}{l}\text { Intent to Reuse }\left(\mathrm{R}^{2}\right. \\
\text { explained variance })\end{array}$ & $\begin{array}{c}\text { between } 35 \% \mathrm{e} \\
68 \%\end{array}$ & $49,40 \%$ & $57,40 \%$ & $73 \%$ & $72 \%$ \\
\hline
\end{tabular}

Still comparing the results with those of other studies, the contructs factor loadings-in addition to the articles development and test WebQual scale Loiacono et al. (2007) was also statistically significant in the study of Ferreira (2015) and Sun et al. (2015). In the last one, there was also nomological validity of the quality constructs, satisfaction and intention to reuse the site.

\subsection{Contributions}

This study's theoretical contribution lies in the validation of WebQual Model Loiacono et al. (2007), as well as the extended model validation with the construct familiarity inclusion. Given the lack of discriminant validity between satisfaction and familiarity, it appears that the gain in the explained variance of the construct satisfaction should not be taken into consideration. Thus, the original WebQual Model showed good indicators regarding one-dimensionality, reliability and convergent validity, discriminant and nomological.

It also tried to adapt and extend the original model with the inclusion of a new construct based on theoretical concepts arising from published studies and the possibility of comparing results obtained previously. Theoretically, it can be affirmed that the two portals perceived quality is reasonable, the reliability coefficients have high consistency and convergent validity, discriminant and nomological are appropriate.

The portals' perceived quality is reasonable, and the constructs that showed unfavorable ratios were on-line completeness and innovativeness. From these results, the first shows the case where the site does not allow interaction between users and managers. However, these figures also reveal the need for encouragement of managerial action to improve the quality, based on creativity and innovation in the policy portal's reformulation.

Regarding managerial implications, it can be highlight the importance need of management action incentive to improve the perceived quality and its increase in the portals queries environment. Construct on-line completeness demonstrates the lack of interaction between portals users, which suggests to managers the introduction of mechanisms to motivate people to refer to the portals. The innovativeness construct indicates that the portals marketers should be encouraged, especially in their efforts to offer more information on products offered on the portals with the use of the best visual identity to illustrate its features, with graphic comparison products. These implications resolution may allow to develop a more complete picture of the portals' quality and external appearance.

It is also important to note that this research can be a valuable tool for measuring the sites quality assessment. It is a useful contribution in the internet field, providing the means that marketing researchers and practitioners need to evaluate sites. As the results indicate that the model can represent some sites perceived quality, the WebQual dimensions may be a reference to the process of improving the sites information, content, functionality, technology, and design. For managers, the factors that make up the model will be key items in the services provision to current and potential customers and in the communication process with them. 


\subsection{Study Limitations and Future Studies}

Data were collected through electronic means in non-probabilistic convenience sampling electronically and therefore it is not possible to generalize the results obtained in this study and the possibility of bias occurrence in the sample elements process selection (Malhotra, 2013).

In new studies terms, it could focus on different services types offered by websites such as: e-commerce, document request, and information (schools, universities, for example), electronic government sites (opening processes, and others), also as institutional sites and social media tools.

Besides that, another item that can be searched is related to the parsimony of the models, considering that the models tested are very large. Research in which at least the same statistical results can be achieved (or even better results) with a smaller number of constructs it can be considered a significant contribution.

\section{References}

Anand, O., Mittal, A., Moolchandani, K., Kagzi, M. M., \& Kar, A. K. (2015). Evaluating travel websites using WebQual: A group decision support approach. In R. Buyya, \& S. M. Thampi (Eds.), Intelligent Distributed Computing (Vol. 321, pp. 151-160). Springer International Publishing. https://doi.org/10.1007/978-3-319-11227-5_14

Aziz, N. A., \& Yasin, N. M. (2010). Analyzing the brand equity and resonance of banking services: Malaysian consumer perspective. International Journal of Marketing Studies, 2(2), 180-189. https://doi.org/10.5539/ijms.v2n2p180

Belanche, D., Casaló, L. V., \& Guinali'u, M. (2011). Website usability, consumer satisfaction and the intention to use a website: The moderating effect of perceived risk. Journal of retailing and consumer services, 19(1), 124-132. https://doi.org/10.1016/j.jretconser.2011.11.001

Bolar, K. (2014). End-user Acceptance of technology interface in transaction based environment. Journal of Internet Banking and Commerce, 19(1), 1-16. Retrieved from http://www.icommercecentral.com/open-access/enduser-acceptance-of-technology-interface-in-transactionbased-environment.pdf

Borges, F. R., Veiga, R. T., Gonçalves Filho, C., Fernandes, I. B., \& Torres, J. N. (2014). Qualidade em serviços e gestão da experiência do cliente no comércio eletrônico. Revista Pensamento Contemporâneo em Administração, 8(2), 126-143. https://doi.org/10.12712/rpca.v8i2.400

Chang, K. C., Chen, M. C., Hsu, C. L., \& Kuo, N. T. (2012). Integrating loss aversion into a technology acceptance model to assess the relationship between website quality and website user's behavioural intentions. Total Quality Management \& Business Excellence, 23(7-8), 913-930. https://doi.org/10.1080/14783363.2011.637793

Chen, R. F., Hsiao, J. L., \& Hwang, H. G. (2012). Measuring customer satisfaction of internet banking in Taiwan: Scale development and validation. Total Quality Management \& Business Excellence, 23(7-8), 749-767. https://doi.org/10.1080/14783363.2012.704284

Curi, W. R., Dias, A. T., \& Filho, C. G. (2006). A percepção dos clientes quanto à qualidade dos sites na Internet: Aplicação e validação do modelo WebQual. In Proceedings XXX ENANPAD. Associação Nacional de Pós-Graduação em Administração. $\quad$ Retrieved from http://www.anpad.org.br/enanpad/2006/dwn/enanpad2006-mkta-2971-resumo.html

Davidavičienè, V., \& Tolvaišas, J. (2012). Measuring quality of e-commerce web sites: Case of Lithuania. Economics and Management, 16, 723-729. Retrieved from https://www.researchgate.net/profile/Vida_Davidavicien/publication/228408548_Measuring_quality_of_e-c ommerce_web_sites_Case_of_Lithuania/links/02e7e52287c8d7d00f000000.pdf

Davis, F. D. (1989). Perceived usefulness, perceived ease of use, and user acceptance of information technology. MIS quarterly, 13(3), 319-340. https://doi.org/10.2307/249008

Dominic, P. D. D., \& Jati, H. (2011). A comparison of Asian airlines websites quality: Using a non-parametric test. International Journal of Business Innovation and Research, 5(5), 599-623. https://doi.org/10.1504/IJBIR.2011.042451

Ferreira, C. M. S. (2015). Qualidade do portal do Ministério Público Português: Aplicação do Modelo WebQual (Master's thesis). Universidade Européia, Lisboa, Portugal. Retrieved from http://comum.rcaap.pt/bitstream/10400.26/10672/2/TMSIG_15_05_C\%C3\%A2ndida\%20Ferreira.pdf 
Fornell, C., Johnson, M. D., Anderson, E. W., Cha, J., \& Bryant, B. E. (1996). The American customer satisfaction index: Nature, purpose, and findings. The Journal of Marketing, 60(4), 7-18. https://doi.org/10.2307/1251898

Franco, J., \& Carlos, F. (2001). Tecnologia de Informação e Negócios na Internet. São Paulo: Atlas.

Granic, A., Mitrovic, I., \& Marangunic, N. (2010). Exploring the usability of web portals: A Croatian case study. International Journal of Information Management, $339-349$. https://doi.org/10.1016/j.ijinfomgt.2010.11.001

Hair, J. R., Black, W. C., Babin, B. J., Anderson, R. E., \& Tathan R. L. (2009). Multivariate Data Analysis. Upper Saddle River: Prentice Hall.

Heijden, H. V. D. (2000). E-Tam: A revision of the technology acceptance model to explain website revisits. $\begin{array}{lllll}\text { Research } & \text { Memorandum, } & \text { 29, } & \text { Retrieved }\end{array}$ http://degree.ubvu.vu.nl/repec/vua/wpaper/pdf/20000029.pdf

Kim, D. J., Ferrin, D. L., \& Rao, H. R. (2003). Trust and satisfaction, two stepping stones for successful e-commerce relationships: A longitudinal exploration. Information Systems Research, 20(2), $237-257$. https://doi.org/10.1287/isre.1080.0188

Lima, K. R., Moura, L. R. C., \& Souki, G. Q. (2015). Proposição e teste de escala de avaliação da qualidade do metrô. Pretexto, 16(3), 21-40.

Loiacono, E. T., Watson, R. T., \& Goodhue, D. L. (2002). WebQual: A measure of website quality. Marketing Theory and Applications, 13(3), 432-438. Retrieved from http://s3.amazonaws.com/academia.edu.documents/30840302/10.1.1.86.4410.pdf?AWSAccessKeyId=AKI AJ56TQJRTWSMTNPEA\&Expires=1484410208\&Signature=6B6Xw1t7lwx1Ex8K0Ut2PZUCuXw\%3D\& response-content disposition=inline \%3B\%20filename\%3DWebQual_A_measure_of_website_quality.pdf

Loiacono, E. T., Watson, R. T., \& Goodhue, D. L. (2007). WebQual: An instrument for consumer evaluation of web sites. International Journal of Electronic Commerce, 11(3), 51-87. https://doi.org/10.2753/JEC1086-4415110302

Loiacono, E., Watson, R. T., \& Goodhue, D. L. (2000). Webqual: A web site quality. Instrument Working paper Worcester Polytechnic Institute, Working Paper.

Malhotra, N. K. (2013). Marketing Research: An Applied Orientation. Upper Saddle River: Prentice Hall. https://doi.org/10.1108/S1548-6435(2013)10

Masoud, E. Y. (2013). The effect of perceived risk on online shopping in Jordan. European Journal of Business and Management, 5(6), 76-87. Retrieved from http://s3.amazonaws.com/academia.edu.documents/31072806/The_Effect_of_Perceived_Risk_on_Online_ Shopping_in_Jordan.pdf?AWSAccessKeyId=AKIAJ56TQJRTWSMTNPEA \&Expires $=\overline{1} 484410394 \&$ Sign ature $=\mathrm{Mdm} \% 2 \mathrm{FNOPsz} 4 \mathrm{IdE7dd} \% 2 \mathrm{FEFQdU5} \% 2 \mathrm{ByJw} \% 3 \mathrm{D} \&$ response-content-disposition=inline $\% 3 \mathrm{~B} \% 20 \mathrm{f}$ ilename\%3DInternational_Journals_Call_for_papers.pdf

Mccoy, S., Everard, A., \& Loiacono, E. T. (2008). Online ads in familiar and unfamiliar sites: Effects on perceived website quality and intention to reuse. Information Systems Journal, 19(4), 437-458. https://doi.org/10.1111/j.1365-2575.2007.00290.x

Mcdougall, S., Reppa, I., Kulik, J., \& Taylor, A. (2016). What makes icons appealing? The role of processing fluency in predicting icon appeal in different task contexts. Applied Ergonomics, 55, $156-172$. https://doi.org/10.1016/j.apergo.2016.02.006

Morgan, A., \& Griego, V. (1998). Easy Use and interpretation of SPSS for Windows: Answering Research Questions With Statistics. New Jersey: Lawrence Erlbaum Associates.

Nawi, N. B. C., \& Mamun, A. (2014). The development of customer satisfaction measurement model for small online apparel businesses in Malaysia. International Journal of Business and Management, 9(10), 39-48. https://doi.org/10.5539/ijbm.v9n10p39

Nunnaly, J. C., \& Bernstein, I. H. (1994). Psychometric Theory. New York: McGraw-Hill.

Petruzzellis, L., D’uggento, A. M., \& Romanazzi, S. (2006). Student satisfaction and quality of service in Italian universities. Managing Service Quality: An International Journal, 16(4), $349-364$. https://doi.org/10.1108/09604520610675694 
Prado, E. P. V. (2010). Sites de internet banking: Uma avaliação da qualidade baseada no modelo WebQual. Gestão \& Regionalidade (On-line), 26(77), 63-74. https://doi.org/10.13037/gr.vol26n77.249

Raposo, W. G., Pereira, R. C. F., \& Santos, J. P. (2008). Qualidade dos sites na internet: Uma aplicação do modelo WebQual em hoteis. In Proceedings XXXIII ENANPAD. Associação Nacional de Pós-Graduação em Administração.

Rodrigues, A. I. F. (2012). Análise às características de qualidade de websites de venda on-line (Master's thesis). Universidade de Coimbra, Coimbra, Portugal. Retrieved from https://estudogeral.sib.uc.pt/jspui/bitstream/10316/21281/1/Tese\%20Mestrado\%20Vers\%C3\%A3o\%20Fina $1 \% 20 \mathrm{DSP}, \mathrm{SA} . \mathrm{pdf}$

Rodrigues, T., \& Andrade, A. (2011). Avaliação externa de ambientes de e-commerce. Gestão $e$ Desenvolvimento, $19, \quad 67-90 . \quad$ Retrieved from http://repositorio.ucp.pt/bitstream/10400.14/9173/1/gestaodesenvolvimento19_67.pdf

Sá, F., Rocha, A., \& Cota, M. P. (2015). Preliminary dimensions for a quality model of electronic local government services. In Proceedings 10th Iberian Conference on Information Systems and Technologies.

Sá, F., Rocha, Á., \& Cota, M. P. (2016). From the quality of traditional services to the quality of local e-Government online services: A literature review. Government Information Quarterly, 33(1), 149-160. https://doi.org/10.1016/j.giq.2015.07.004

Sun, J., Wang, Y., Yang, Z., \& Zhang, Y. (2015). Rethinking E-Commerce service quality: Does website quality still suffice? Journal of Computer Information Systems, 55(4), 62-72. https://doi.org/10.1080/08874417.2015.11645788

Thatcher, J. B., Carter, M., Li, X., \& Rong, G. (2013). A classification and investigation of trustees in B-to-C e-commerce: General vs. specific trust. Communications of the Association for Information Systems, 32, 107-134. Retrieved from http://aisel.aisnet.org/cais/vol32/iss1/4

Vieira, V. A., Matos, C. A. D., \& Slongo, L. A. (2009). Avaliação das relações entre qualidade de serviço do site, satisfação, valor percebido, lealdade e boca a boca por meio de um modelo teórico. Revista de Administração da Universidade de São Paulo, 44(2), 131-146. Retrieved from http://www.redalyc.org/articulo.oa?id=223417531004

\section{Appendix}

Appendix A. Dimensionality values, reliability and validity of dimensions WebQual Model Extended attributes and its consequences

\begin{tabular}{|c|c|c|c|c|}
\hline Construct & Items Description & Average & Component & $\begin{array}{l}\text { Standardized } \\
\text { Factorial Load }\end{array}$ \\
\hline Informational & The site information is useful for what I need & 7.93 & 0.988 & 0.966 \\
\hline Fit-To-Task & \multirow[t]{4}{*}{ The site has the information I need. } & \multirow[t]{4}{*}{7.92} & \multirow[t]{4}{*}{0.991} & \multirow[t]{4}{*}{0.955} \\
\hline V.E. $=97.75 \%$ & & & & \\
\hline $\mathrm{KMO}=0.786$ & & & & \\
\hline E.B. $=3.367,6$ & & & & \\
\hline Sig. $=0.000$ & \multirow[t]{4}{*}{$\begin{array}{l}\text { The information contained on the site helps me } \\
\text { with what I need. }\end{array}$} & \multirow[t]{4}{*}{7.93} & \multirow[t]{4}{*}{0.987} & \multirow[t]{4}{*}{0.962} \\
\hline A.C. $=0.988$ & & & & \\
\hline A.V.E. $=0.923$ & & & & \\
\hline C.C. $=0.973$ & & & & \\
\hline $\begin{array}{l}\text { Tailored } \\
\text { Information }\end{array}$ & $\begin{array}{l}\text { The site allows me to do researches for custom } \\
\text { information I need. }\end{array}$ & 7.41 & 0.988 & 0.950 \\
\hline V.E. $=97.20 \%$ & $\begin{array}{l}\text { The site has features that helps me accomplish } \\
\text { my tasks. }\end{array}$ & 7.42 & 0.987 & 0.940 \\
\hline
\end{tabular}


$\mathrm{KMO}=0.788$

E.B. $=3.107,3$

Sig. $=0.000$

A.C. $=0.986$

I can use the site to get information tailored to

my specific needs.

0.983

0.943

A.V.E. $=0.892$

C.C. $=0.961$

Relative advantage

V.E. $=93.95 \%$

Is better to use the site, then to call the Real

Estate (s). Associate (s).

6.03

0.967

0.921

$\mathrm{KMO}=0.776$

E.B. $=2.229,5$

It is easier to use the site to complete my

business than with the (s). Real Estate (s)

Associate (s) by telephone, fax or email a

6.02

0.976

0.927

Sig. $=0.000$

representative.

A.C. $=0.996$

A.V.E. $=0.847$

C.C. $=0.943$

Trust

V.E. $=93.82 \%$

$\mathrm{KMO}=0.761$

E.B. $=2.288,3$

The site is an alternative to use, instead of

calling the (s) Real Estate (s) Associate (s).

6.53

0.964

0.913

Confidence.

I feel safe with the information obtained on the site.

6.66

0.955

0.815

I believe the site will keep my personal

information secure.

6.83

0.978

0.979

Sig. $=0.000$

A.C. $=0.967$

A.V.E. $=0.790$

I believe that those responsible for the site will not use my personal information improperly.

6.85

0.972

0.863

C.C. $=0.918$

Response time

V.E. $=95.67 \%$

$\mathrm{KMO}=0.749$

The site response time for my researches or actions is very small.

6.01

0.962

0.827

6.03

0.987

0.988

E.B. $=2.958,8$

Sig. $=0.977$

A.C. $=0.977$

The site takes little time to load pages.

6.04

0.985

0.954

A.V.E. $=0.856$

C.C. $=0.947$

Easy of

understanding

V.E. $=96.65 \%$

The pages displayed by the site are easy to read

7.34

0.993

0.939

The texts contained on the site are easy to understand.

7.34

0.994

0.942

$\mathrm{KMO}=0.765$

E.B. $=3.933,9$

Sig. $=0.000$

A.C. $=0.993$

The sites subtitles or sections are easy to understand.

0.993

0.975

A.V.E. $=0.907$

C.C. $=0.967$

Intuitive operation

It is easy for me to learn to use the site.

7.87

0.988

0.955

V.E. $=97.33 \%$

It's easy for me to use better and better the site over time. 


$$
\mathrm{KMO}=0.779
$$

E.B. $=3.221,5$

Sig. $=0.000$

A.C. $=0.986$

A.V.E. $=0.897$

C.C. $=0.963$

Visual appeal

The site is visually pleasing.

6.84

0.984

0.970

V.E. $=96.60 \%$

The site is visually appealing.

$\mathrm{KMO}=0.789$

E.B. $=2.872,1$

Sig. $=0.000$

A.C. $=0.982$

The site has a nice style.

6.67

0.984

0.970

A.V.E. $=0.932$

C.C. $=0.976$

Innovativeness

The site is innovative

5.17

0.988

0.975

V.E. $=97.82 \%$

The site is creative.

4.90

0.994

0.996

$\mathrm{KMO}=0.761$

E.B. $=3.499,5$

Sig. $=0.000$

A.C. $=0.988$

The website design is innovative.

4.96

0.985

0.967

A.V.E. $=0.959$

C.C. $=0.986$

Emotional appeal

I feel glad when I use the site.

6.80

0.984

0.961

V.E. $=95.99 \%$

I feel good when I use the site.

6.81

0.986

0.979

$\mathrm{KMO}=0.763$

E.B. $=2.845,8$

Sig. $=0.000$

A.C. $=0.977$

I feel more sociable or socially integrated when using the site.

A.V.E. $=0.896$

C.C. $=0.963$

Consistent image

V.E. $=94.98 \%$

$\mathrm{KMO}=0.741$

E.B. $=2.892,9$

The site projects an image consistent with the company's image.

6.96

0.984

0.947

The site is consistent with the image that I have of the company.

6.97

0.985

0.977

Sig. $=0.000$

A.C. $=0.970$

A.V.E. $=0.883$

C.C. $=0.958$

On-Line

Completeness

V.E. $=89.51 \%$

The site allows online communications.

3.49

0.926

0.798

All my communication can be done through the

5.61

0.967

0.996

$\mathrm{KMO}=0.736$

0.842 site.

Most of my personal or business processes can

6.11

0.945 


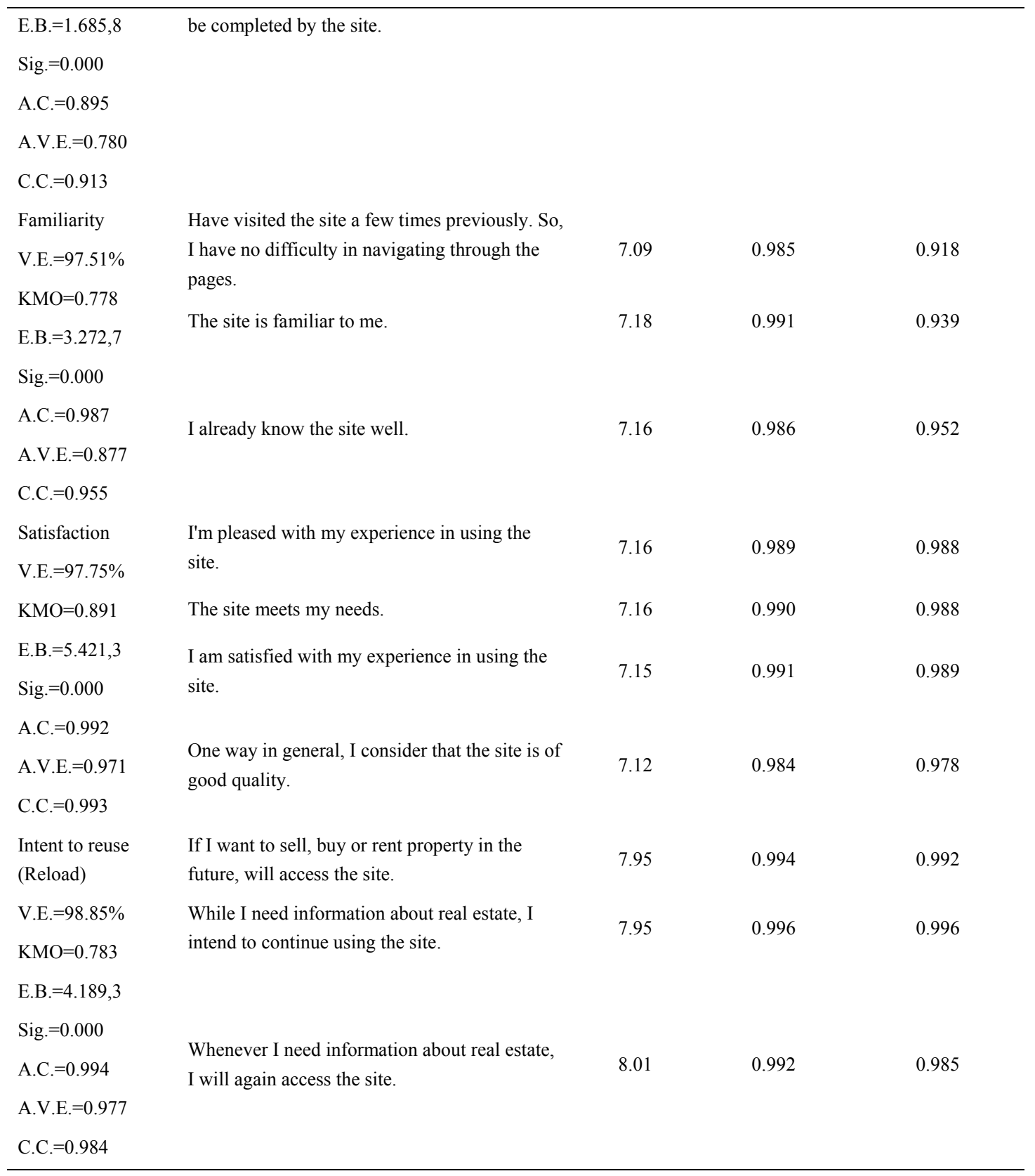

\section{Copyrights}

Copyright for this article is retained by the author(s), with first publication rights granted to the journal.

This is an open-access article distributed under the terms and conditions of the Creative Commons Attribution license (http://creativecommons.org/licenses/by/4.0/). 